\title{
Fundoplication for gastroesophageal reflux and factors associated with the outcome 6 to 10 years after the operation: multivariate analysis of prognostic factors using the propensity score
}

\author{
J. Hafez $\cdot$ F. Wrba $\cdot$ J. Lenglinger $\cdot$ \\ J. Miholic
}

Published online: 20 August 2008

(C) Springer Science+Business Media, LLC 2008

Erratum to: Surg Endosc (2008) 22(8):1763-1768

DOI 10.1007/s00464-008-9872-5

In Volume 22, Number 8, page 1765, lines 5-7, the sentence "An intestinal metaplasia was defined by the presence of
Alcian blue-stained globlet cells in the esophageal squamous epithelial tissue." should be changed to "An intestinal metaplasia was defined by the presence of Alcian bluestained globlet cells in the columnar lined esophageal mucosa."

The online version of the original article can be found under doi:10.1007/s00464-008-9872-5.

J. Hafez $(\bowtie) \cdot$ J. Lenglinger · J. Miholic

Department of Surgery, Medical University Vienna, Vienna,

Austria

e-mail: johannes.miholic@meduniwien.ac.at;

Joumanah.Hafez@drv-bund.de

F. Wrba

Department of Pathology, Medical University Vienna, Vienna,

Austria 